\title{
Last Trimester Pregnancy and Glioma: Case Report
}

\author{
Son Trimester Gebelik ve Gliom: Olgu Sunumu
}

\author{
Toptaş KK ${ }^{1}$, Bahat PY ${ }^{1}$, Çakmak $K^{2}$ \\ 1- İstanbul Kanuni Sultan Süleyman Eğitim ve Araştırma Hastanesi, Kadın Hastalıkları ve Doğum Kliniği 2 2- Esenler Kadın Doğum ve Çocuk \\ Hastalıkları Hastanesi, Kadın Hastalıkları ve Doğum
}

\begin{abstract}
The incidence of brain tumors that become symptomatic during pregnancy is decreased compared to women of the same age. These tumors originating from glial cells are intrinsic parenchymal tumors that can be slowgrowing or aggressive and invasive depending on the degree. They typically present with nonspecific symptoms such as headache, nausea, and vomiting. Brain tumors that occur during pregnancy carry serious risks for both mother and fetus. The 33-week pregnant patient presented to our clinic with the complaint of emergency labor, and it was learned that in her medical history she had epilepsy attacks every day in the last month. Previous examinations of the patient were repeated in consultation with neurology and neurosurgery, and glioblastoma was detected in the right temporal region of the patient. A multidisciplinary approach and treatment of brain tumors during pregnancy should be performed according to the patient.

ÖZET

Gebelikte semptomatik hale gelen beyin tümörlerinin görülme sılkl̆̆̆, aynı yaștaki kadınlardakine kiyasla azalmış görülmektedir. Glial hücrelerden kaynaklanan bu tümörler, derecesine bağlı olarak yavaș büyüyen veya agresif ve invaziv olabilen intrinsik parankimal tümörlerdir. Tipik olarak baş ağrısı, bulantı ve kusma gibi nonspesifik semptomlarla ortaya çıkarlar. Gebelikte ortaya çıkan beyin tümörleri hem anne hem fetus için ciddi riskler taşımaktadır. Acil kadın doğuma sancı şikayetiyle başvuran 33 hafta gebe hastanın anamnezinde son 1 ayda her gün epilepsi atakları olduğu ögrenildi. Hastanın daha önceki tetkikleri nöroloji ve nöroșirurjiye danışllarak tekrarlandı ve hastanın sağ temporal bölgede glioblastom saptandı. Gebelikte beyin tümörleri multidisipliner yaklaşllmalı ve tedavisinde hastaya göre hareket edilmelidir.
\end{abstract}

Key Words:

Glioma,

Pregnancy,

Brain tumor

Anahtar Kelimeler:

Gliom,

Gebelik,

Beyin tümörü.

\section{GíRiş}

Primer malign beyin tümörlerinin yıllık insidans1 100.000 'de 2.6dır; glioma en yaygın histolojik tiptir. Gebe kadınlarda primer beyin tümörlerinin görülme sıklığı biraz daha düşüktür, ancak her beyin tümör tipinin göreceli sıklığı gebe ve gebe olmayan kadınlarda benzer görülmektedir. Beyin tümörü tedavilerindeki yeni gelişmeler, özellikle düşük dereceli gliomalar için, genel olarak daha iyi prognozla sonuçlanmıştır(1). Gebelikte semptomatik hale gelen beyin tümörlerinin görülme sıklığı, aynı yaştaki kadınlara kıyasla azalmıştır(2). Gliomlar, glial hücrelerden kaynaklanan instrinsek parankimal tümörlerdir. Derecesine bağlı olarak agresif ve invaziv olabildikleri gibi yavaş büyüme de gösterebilirler (3). Daha çok bulant1, kusma ve baş ağrısı gibi nonspesifik bulgularla ortaya çıkmaktadırlar. Fokal nörolojik defisitler ve nöbet görülen diğer semptomlardır. Beyin tümörleri gebelikte anne ve bebek için ciddi riskler taşımaktadır. Hastalık multidisipliner yönetilmelidir.

\section{OLGU}

24 yaşında gravide 3 parite 2, daha önce normal vajinal doğum yapmış olan 33 hafta 5 günlük gebe acil kadın doğum servisine sancı şikayeti ile başvurdu. Hastanın yapılan muayenesinde fetal kalp atımı pozitif, servikal kanal uzunluğu $10 \mathrm{~mm}$, vajinal tuşede $2-3 \mathrm{~cm}$ açıklık izlendi. Non-stres testte kontraksiyonları bulunan hasta erken doğum tehdidini önlemek ve medikal tedavi amaçlı perinatoloji servisine yatırıldı. Hastadan alınan anamnezde son 1 aydır her gün nöbet geçirdiği ve levetirasetam $5002 * 1$ kullandığı bilgisi alındı. Hastaya tokolitik amaçlı nifedipin $10 \mathrm{mg} 8 * 1$ başlandı. Betametazon toplam $12 \mathrm{mg}$ olarak 24 saatte yapilması planlandı ve $6 \mathrm{mg}$ ilk dozu yapıldı. Baş ağrısı ve nöbet şikayeti olan hastaya kranial MRI planland,, MRI sonucunda ön planda ensefalit düşünüldü ve intrakranial kitle ayırımı açısından difüzyon MRI istenmesi uygun görüldü. Dış merkezde ensefalit tedavisi ve geçirdiği nöbet nedeni ile epilepsi tedavisi başlandığı bilgisi alındı. Hasta tarafımızca nöroloji kliniğine konsülte edildi ve nöroloji uzmanı tarafindan istenen MRI ile değerlendirildi. Sağda temporal lobda kortikosubkortikal alanda parahipokampal gyrusa uzanımı olan geniş FLAIR ve T2 A serilerde hiperintens, bulunduğu alanda kortikal kalınlaşmaya neden olan gliozis sahası izlendi (Resim 1). Bu bulgu göz önüne alındığında ayırıcı tanı listesinde öncelikle glial $\mathrm{Tm}$ düşünüldü. Kontrastlı MRI, EEG ve enfeksiyon konsültasyonu 


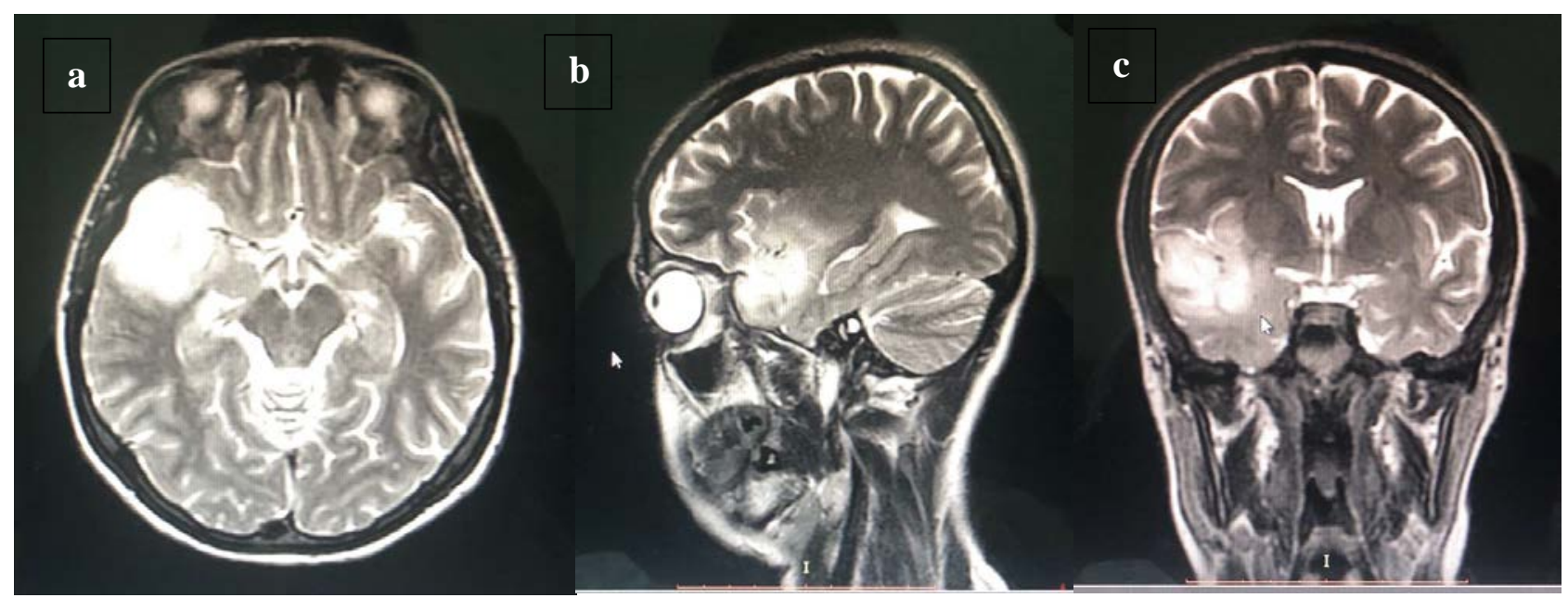

Resim 1: Sağ temporal lobda kortikal kalınlaşmaya neden olan gliozis alanı MR görüntüsü a)Horizantal kesit b)Sagital kesit c)Koronal kesit

istendi. Enfeksiyona konsülte edilen hastada ensefalit düşünülmedi. Betametazon 2. doz 24 saat sonra yapıldı. 48 saatlik takiplerinde servikal uzunluk $30 \mathrm{~mm}$ olan hastanın nidilat tedavisi sonlandırıldı. Spektroskopi Manyetik Rezonans Görüntülemede; Sağ temporal düzeyde yaklaşık $4 \times 3 \mathrm{~cm}$ lik alanda flair hiperintens lezyon alanı izlendi. Metabolik değerler şeklinde spektroskopi örnekleri gözlenmedi (düşük grade glial Tm ?). şeklinde raporlandı. Takipler sırasında hastanın serviste absans nöbet geçirdiği izlendi ve nöroşürirji ve nöroloji konsültasyonu istendi. Nöroşirürji tarafindan hastanın sağ temporal bölgede glioblastom ile uyumlu görüntü izlendiği acil cerrahi düşünülmediği doğum sonrası kontrastlı MRI sonucu ile yeniden değerlendirilmesi istendi. Nöroloji tarafindan EEGsi görülen hasta tetaform yavaşlama görüldüğü ve levotrasetam dozunun $2 * 750 \mathrm{mg}$ olarak düzenlemesi önerildi. Levetirasetam dozunun artırılmasından sonra hastanın tekrar nöbet geçirmediği görüldü. Gebelik haftası 35 hafta 1 gün olan hastaya perinatoloji servisinde takibi sirasinda NST'de fetal distress saptanması üzerine sezaryen endikasyonu verildi. Genel anestezi altında hastaya sezaryen yapıldı. Sezeryan sonrası komplikasyon gelişmeyen hastaya postop 5 . Günde kontrastlı MR çekildi. Sağ tempora - anteriorda $\sim 4,5 \mathrm{x} 4 \mathrm{~cm}$ boyutlarında T2 ve FLAİR hiperintens, T1 izo- hipointens, belirgin kontrast tutulumu göstermeyen nodüler lezyon alanı izlendi. Düşük gradeli glial tümör olarak raporlandı. Nöroloji ve nöroşirürji tarafından 6 ay sonra poliklinik kontrolü önerisi ile taburcu edildi.

\section{TARTIŞMA}

Gebelikte beyin tümörleri anne ve bebek açısından ek riskler oluşturmakta, bu tümörlere multidisipliner yaklaşım gerekmektedir. Reproduktif çağdaki kadınlarda en sık görülen intrakranial tümör glial tümörlerdir (3). Yapılan çalışmalar, gliom ve gebelik arasında tümör yükü, tümör artış hızı ve nöbet sıklığı açısından korelasyon varlığını göstermiştir (4). Yapılan çok merkezli bir çalışmada daha önce gliom tanısı alan ve gebe kalan 24 hasta ile hamilelik sirasinda tanı alan 28 gebe incelenmiş, bu hastalarda gebelik süresi boyunca tümör çapının büyüdüğü tespit edilmiştir. $\mathrm{Bu}$ hastalardan 3'üne gebelik sırasında cerrahi, 1 hastaya da radyoterapi ve cerrahi birlikte uygulanmıştır (5). Beyin tümörlerinin gebelik sırasında ilerlemesini açıklamak için çeşitli teoriler ortaya atılmıştır. Gebelik sırasında anjiyogenik faktörler ve büyüme faktörlerinin düzeyindeki artışın, hormonal değişikliklerin, beyin tümörlerinin büyüme hızını etkilediğini göstermektedir (6). Kusma, baş ağrısı ve nöbetler gebeliğin erken dönemlerinde hiperemezis gravidarum veya ilerleyen gebelik haftalarında preeklampsi ile karıştırılabilir. Görme bozukluğu, ekstremite güçsüzlüğü, nöbetler gibi nörolojik defisitlerin varlığında intrakraniyal lezyon olasılığı akılda tutulmalı ve tanı için MRI gibi ileri tetkik yapılması düşünülmelidir. Olgumuzda gebelik öncesinde hastanın beyin tümörü tanısı bulunmamaktadır. Gebelik sırasında görülen gliom vakaları literatürde nadir bulunmaktadır. Gebelikte, beyin tümörü tedavisinde hastaya göre karar verilmelidir. Tanı konulan gebelik haftası, intrakranial patoloji ve anne babanın isteği göz önünde bulundurulmalıdır. Beyin tümörü tanısı almış gebelerde cerrahi bir seçenektir. Ancak bizim olgumuzda cerrahi açıdan izlem önerilmiştir. Nörolojik bulgusu olmayan ve tümör boyutları küçük olan hastalarda cerrahi tedavi gebelik sonlandıktan sonra planlanabilir. Hastalığın seyrine göre gebeliğin miadından önce sonlandırmak zorunda kalınması yenidoğan yoğun bakım ihtiyacını arttırmaktadır. Normal doğum sırasında intrakranial basınç artışına bağlı oluşabilecek komplikasyonlar nedeniyle bu hastalarda sezeryan ile doğum ön planda düşünülmelidir. 


\section{SONUÇ}

Gebeliğe bağlı olarak bulantı kusma gibi semptomların görülmesi beyin tümörlerinin de nonspesifik semptomları olduğundan gebelerde beyin tümörü tanısını koymakta geç kalınmasına neden olabilir. Gebede inatçı baş ağrısı, bulantı ve kusma semptomlarında beyin tümörü ihtimali akılda tutulmalı, ileri tetkikler yapılmalıdır.

Tanı konulduktan sonra, kadın doğum hekimi, beyin cerrahı ve çocuk doktorundan oluşan bir ekiple beraber tedavi kararı verilmelidir.

Çıkar çatışması

Tüm yazarlar çıkar çatışması olmadığını beyan eder.

\section{KAYNAKLAR}

1. Pregnancy and glial brain tumors Shlomit Yust-Katz, John F. de Groot, Diane Liu, Jimin Wu, Ying Yuan, Mark D. Anderson, Charles A. Conrad, Andrea Milbourne, Mark R. Gilbert, and Terri S. Armstrong. Neuro Oncol. 2014 Sep; 16(9): 1289-1294.

2. Pregnancy-related primary brain and spinal tumors.Roelvink NC, Kamphorst W, van Alphen HA, Rao BR., Arch Neurol. 1987 Feb;44(2):209-15.

3. Challenges of glioma and pregnancy: a systematic review. A. van Westrhenen, J. T. Senders, E. Martin, A. C. Di Risio, and M. L. D. Broekman. J Neurooncol. 2018; 139(1): 1-11.

4. Interactions between glioma and pregnancy: insight from a 52-case multicenter series. Peeters S et al, J Neurosurg. 2018 Jan;128(1):3-13.

5. Sex steroid and growth factor profile of a meningioma associated with pregnancy.Smith JS, Quiñones-Hinojosa A, Harmon-Smith M, Bollen AW, McDermott MW. Can J Neurol Sci. 2005 Feb;32(1):122-7.

6. Influence of pregnancy on glioma patients. Forster MT, Baumgarten P, Gessler F, Maurer G, Senft C, Hattingen E, Seifert V, Harter PN, Franz K. Acta Neurochir (Wien). 2019 Mar;161(3):535-543. 